\title{
Stunting berhubungan dengan perkembangan motorik anak di Kecamatan Sedayu, Bantul, Yogyakarta
}

\author{
Stunting associated with children motoric development in Sedayu Subdistrict, Bantul, Yogyakarta
}

\author{
Maria Goreti Pantaleon ${ }^{1}$, Hamam Hadi², Indria Laksmi Gamayanti ${ }^{3}$
}

\begin{abstract}
Background: Stunting (short body length) is a body condition that is very short until surpass deficit at 2 $S D$ under median of body length or body height of the population that be an international reference. The cause of stunting is food consumption that is not balanced and infectious disease. Many studies showed the correlation between stunting and poor motoric and mental development in early childhood, and poor cognitive performance and school performance in later childhood. The national prevalence of stunting in 2013 was 37.2\%, it increased compared to 2010 (35.6\%) and 2007 (36.8\%).

Objectives: To know the correlation between stunting incidence and the development of 6-23 months old children in Sedayu Subdistrict, Bantul, Yogyakarta.

Methods: This was observational study with cross sectional design. The sample size was 100 children, whose aged 6-23 months old. They consisted of 50 stunting children and 50 non-stunting children who were selected by consecutive sampling methods. Data were collected by using structured questionnaire and assisted by psychologist to measure the development of the children. Stunting in 6-23 months old children was measured by indicator of body length for age (WHO 2005) and the measurement of development used method of Bayley Scales of Infant Development III. Data were analyzed using chi-square test and logistic regression test by $95 \%$ confidence interval.

Results: Statistically, there was significant correlation between stunting and motoric development of the toddler $(p=0.002)$, but there was no significant correlation between stunting and the development of cognitive, language, socio- emotional, and adaptive of the toddler. The result of multivariate showed that stunting and sex statistically had correlation to the motoric development $(p<0.05)$.

Conclusions: Stunting associated with children motoric development in Sedayu Subdistrict, Bantul, Yogyakarta
\end{abstract}

KEYWORDS: children development, stunting

\begin{abstract}
ABSTRAK
Latar belakang: Stunting (tubuh pendek) adalah keadaan tubuh yang sangat pendek hingga melampaui defisit $2 S D$ di bawah median panjang atau tinggi badan populasi yang menjadi referensi internasional. Penyebab stunting adalah konsumsi makanan yang tidak seimbang dan penyakit infeksi. Sejumlah penelitian memperlihatkan keterkaitan antara stunting dengan perkembangan motorik dan mental yang buruk dalam usia kanak-kanak dini, serta prestasi kognitif dan prestasi sekolah yang buruk dalam usia kanak-kanak lanjut. Prevalensi stunting secara nasional tahun 2013 adalah 37,2\%, yang berarti terjadi peningkatan dibandingkan tahun 2010 (35,6\%) dan 2007 (36,8\%).

Tujuan: Untuk mengetahui hubungan antara kejadian stunting dengan perkembangan anak usia 6-23 bulan di Kecamatan Sedayu, Bantul, Yogyakarta.

Metode: Penelitian ini merupakan penelitian observasional dengan rancangan cross sectional. Sampel penelitian sebanyak 100 anak yang berusia 6-23 bulan, terdiri dari 50 baduta stunting dan 50 baduta tidak

\footnotetext{
1 Jurusan Gizi Poltekkes Kemenkes Kupang, Jl. RA Kartini I Kecamatan Kelapa Lima, Kota Kupang, NTT, e-mail: margotepunk@gmail. com

${ }^{2}$ Magister Gizi dan Kesehatan, Fakultas Kedokteran Universitas Gadjah Mada, Jl. Farmako, Sekip Utara, Yogyakarta, 55281, e-mail: hamamhadi99@gamail.com.

${ }^{3}$ RSUP Dr. Sardjito Bagian Klinik Tumbuh Kembang Anak, Jl. Kesehatan, Yogyakarta 55281, e-mail: gmyanti@yahoo.com
} 
stunting, dan dipilih dengan metode consecutive sampling. Pengambilan data menggunakan kuesioner terstruktur dan dibantu oleh tenaga psikolog dalam pengukuran perkembangan anak. Stunting pada anak usia 6-23 bulan diukur menggunakan indikator panjang badan menurut umur dan pengukuran perkembangan anak menggunakan metode Bayley Scales of Infant Development III. Analisis data menggunakan uji chi-square dan regresi logistik dengan 95\% confident interval.

Hasil: Secara statistik, ada hubungan signifikan antara stunting dengan perkembangan motorik baduta $(p=0,002)$, namun tidak terdapat hubungan signifikan antara stunting dengan perkembangan kognitif, bahasa, sosioemosional, dan perkembangan adaptif baduta. Hasil uji multivariat menunjukkan bahwa stunting dan jenis kelamin secara statistik berkaitan dengan perkembangan motorik $(p<0,05)$.

Kesimpulan: Ada hubungan signifikan antara stunting dengan perkembangan motorik baduta di Kecamatan Sedayu, Bantul, Yogyakarta.

KATA KUNCI: perkembangan anak, stunting

\section{PENDAHULUAN}

Stunting (tubuh pendek) adalah keadaan tubuh yang sangat pendek hingga melampaui defisit 2 SD di bawah median panjang atau tinggi badan populasi yang menjadi referensi internasional. Stunting menggambarkan keadaan gizi kurang yang sudah berjalan lama dan memerlukan waktu bagi anak untuk berkembang serta pulih kembali. Sejumlah penelitian memperlihatkan keterkaitan antara stunting dengan perkembangan motorik dan mental yang buruk pada usia kanak-kanak dini, serta prestasi kognitif dan prestasi sekolah yang buruk pada usia kanak-kanak lanjut (1).

Beberapa penelitian telah menemukan keterkaitan antara pertumbuhan tinggi badan dan perubahan perkembangan pada usia 3 tahun pertama. Studi pada binatang menunjukkan bahwa serebellum otak yang mengoordinasi gerak motorik merupakan bagian yang paling rentan rusak pada masa bayi, sehingga malnutrisi di awal kehidupan anak akan menghambat perkembangan motorik. Pada anak yang mengalami stunting diduga akan mempunyai aktivitas motorik yang rendah (2).

Prevalensi stunting secara nasional tahun 2013 adalah $37,2 \%$, yang berarti terjadi peningkatan dibandingkan tahun 2010 (35,6\%) dan tahun 2007 $(36,8 \%)$ (3). Data dari Dinas Kesehatan Kabupaten Bantul tahun 2012 memperlihatkan prevalensi stunting sebesar $18,08 \%$ (4). Meskipun prevalensi stunting di Kabupaten Bantul lebih rendah daripada prevalensi nasional, angka ini merupakan yang tertinggi ke-2 di Provinsi Daerah Istimewa Yogyakarta (DIY). Selain itu, faktor-faktor yang berhubungan dengan stunting seperti berat bayi lahir rendah (BBLR), ibu hamil yang menderita kekurangan energi kronik (KEK), dan ibu hamil anemia masih menjadi masalah di Kabupaten Bantul. Untuk itu, perlu dilakukan penelitian mengenai hubungan antara kejadian stunting dengan perkembangan anak usia 6-23 bulan, dengan harapan apabila ditemukan permasalahan dapat ditangani sejak dini, sehingga tidak berdampak lebih lanjut.

\section{BAHAN DAN METODE}

Penelitian ini menggunakan desain cross sectional yang dilakukan di Kecamatan Sedayu, Bantul, Yogyakarta selama bulan Mei hingga Juli tahun 2014. Penelitian ini merupakan bagian dari penelitian yang berjudul "Status Gizi lbu Hamil dan Baduta di Kecamatan Sedayu, Kabupaten Bantul, Daerah Istimewa Yogyakarta yang dilaksanakan oleh Alma Ata Center For Healthy Life and Food (ACHEAF). Subjek penelitian ini adalah anak usia 6-23 bulan di Kecamatan Sedayu yang telah sesuai dengan kriteria inklusi dan eksklusi. Sampel penelitian diambil menggunakan teknik consecutive sampling, yaitu semua responden yang memenuhi kriteria diundang untuk mengikuti penelitian dan dikumpulkan di satu lokasi, sampai terpenuhi jumlah sampel yang dibutuhkan. Dari 106 responden yang diundang, hanya 100 anak yang dapat mengikuti penelitian sampai selesai, sehingga sampel yang diperoleh sebanyak 100 anak.

Variabel terikat pada penelitian ini adalah perkembangan anak usia 6-23 bulan di Kecamatan 
Sedayu, Kabupaten Bantul, sementara variabel bebas yaitu stunting. Variabel luar yaitu jenis kelamin, ASI eksklusif, riwayat BBLR, asupan energi, dan protein, pendidikan orangtua, dan pendapatan keluarga.

Setelah memperoleh izin dari Komisi Etik dengan nomor Ref: KE/FK/382/EC, dilakukan pengambilan data melalui wawancara kepada orangtua/ pengasuh anak dengan menggunakan kuesioner, pengukuran perkembangan anak menggunakan metode Bayley Scale of Infant Development Third (BSID-III), dan penentuan status gizi menggunakan metode antropometri dengan pengukuran panjang badan anak di bawah dua tahun menggunakan infantometer ketelitian $0,1 \mathrm{~cm}$.

Validasi kuesioner dilakukan pada 30 responden yang tersebar di 60 posyandu dan dipilih secara acak. Peneliti sebelumnya dilatih untuk melakukan pengukuran antropometri dan pengukuran perkembangan anak untuk menghindari terjadinya kesalahan dalam pengukuran.

\section{HASIL}

Hasil penelitian pada Tabel 1 menunjukkan bahwa total responden anak di bawah dua tahun sebanyak 100 orang, yang terdiri dari 58 laki-laki dan 42 perempuan. Anak dengan riwayat BBLR, tidak memperoleh ASI eksklusif, serta asupan energi dan protein kurang, lebih banyak yang mengalami stunting. Anak stunting lebih banyak memiliki perkembangan motorik, kognitif, sosioemosional, dan adaptif di bawah rata-rata jika dibandingkan dengan anak yang tidak mengalami stunting.

Hasil analisis pada Tabel 2 diketahui bahwa perkembangan motorik anak yang stunting lebih banyak yang kurang (22\%) jika dibandingkan dengan anak yang tidak stunting (2\%). Selain itu, proporsi anak yang perkembangan motoriknya baik adalah $20 \%$ lebih tinggi pada anak yang tidak stunting. Hasil uji statistik diperoleh nilai $p=0,002$, maka dapat disimpulkan ada hubungan yang signifikan antara stunting dengan perkembangan motorik anak di bawah dua tahun.

Hasil analisis pada Tabel 3 diperoleh bahwa perempuan lebih banyak mempunyai perkembangan motorik kurang $(23,81 \%)$ jika dibandingkan dengan laki-laki $(3,45 \%)$. Selain itu, proporsi anak laki-laki yang perkembangan motoriknya baik sebesar $20,36 \%$ lebih tinggi daripada anak perempuan. Hasil uji statistik diperoleh nilai $p=0,002$, maka dapat disimpulkan bahwa ada hubungan yang signifikan antara jenis kelamin dengan perkembangan motorik anak di bawah dua tahun.

Ibu dengan tingkat pendidikan yang rendah lebih banyak memiliki anak dengan perkembangan motorik kurang $(12,82 \%)$ jika dibandingkan dengan ibu dengan tingkat pendidikan tinggi $(11,48 \%)$. Hasil uji statistik diperoleh nilai $p=0,840$, maka dapat disimpulkan bahwa tidak ada hubungan signifikan antara tingkat pendidikan ibu dengan perkembangan motorik anak di bawah dua tahun (Tabel 3).

Ayah dengan tingkat pendidikan yang rendah lebih banyak memiliki anak dengan perkembangan motorik kurang $(13,89 \%)$ jika dibandingkan dengan ayah yang berpendidikan tinggi $(10,94 \%)$. Hasil uji statistik diperoleh nilai $p=0,663$, maka dapat disimpulkan bahwa tidak ada hubungan signifikan antara tingkat pendidikan ayah dengan perkembangan motorik anak di bawah dua tahun (Tabel 3).

Hasil analisis riwayat pemberian ASI eksklusif menunjukkan bahwa anak yang tidak mendapatkan ASI eksklusif lebih banyak memiliki perkembangan motorik kurang $(15,38 \%)$ jika dibandingkan dengan anak yang mendapatkan ASI eksklusif (8,33\%). Hasil uji statistik diperoleh nilai $p=0,278$, maka dapat disimpulkan bahwa tidak ada hubungan signifikan antara riwayat pemberian ASI eksklusif dengan perkembangan motorik anak di bawah dua tahun (Tabel 3).

Hasil analisis riwayat BBLR menunjukkan bahwa anak yang mempunyai riwayat BBLR, lebih banyak memiliki perkembangan motorik di bawah rata-rata $(14,29 \%)$ jika dibandingkan dengan anak yang tidak memiliki riwayat BBLR $(11,83 \%)$. Hasil uji statistik diperoleh nilai $p=0,847$, maka dapat disimpulkan bahwa tidak ada hubungan signifikan antara riwayat BBLR dengan perkembangan motorik anak di bawah dua tahun (Tabel 3).

Anak dengan asupan energi kurang lebih banyak memiliki perkembangan motorik kurang 
Tabel 1. Karakteristik dasar responden penelitian

\begin{tabular}{|c|c|c|c|c|}
\hline \multirow[b]{2}{*}{ Karakteristik anak } & \multicolumn{4}{|c|}{ Status gizi anak } \\
\hline & $\begin{array}{c}\text { Tidak stunting } \\
\text { (n) }\end{array}$ & $\%$ & $\begin{array}{l}\text { Stunting } \\
\text { (n) }\end{array}$ & $\%$ \\
\hline \multicolumn{5}{|l|}{ Jenis kelamin } \\
\hline Laki-laki & 33 & 56,90 & 25 & 43,10 \\
\hline Perempuan & 17 & 40,48 & 25 & 59,52 \\
\hline \multicolumn{5}{|l|}{ Riwayat BBLR } \\
\hline Tidak & 49 & 52,69 & 44 & 47,31 \\
\hline Ya & 1 & 14,29 & 6 & 85,71 \\
\hline \multicolumn{5}{|l|}{ ASI eksklusif } \\
\hline Ya & 34 & 70,83 & 14 & 29,17 \\
\hline Tidak & 16 & 30,77 & 36 & 69,23 \\
\hline \multicolumn{5}{|l|}{ Asupan energi } \\
\hline Cukup & 36 & 59,02 & 25 & 40,98 \\
\hline Kurang & 14 & 35,90 & 25 & 64,10 \\
\hline \multicolumn{5}{|l|}{ Asupan protein } \\
\hline Cukup & 44 & 57,14 & 33 & 42,86 \\
\hline Kurang & 6 & 26,09 & 17 & 73,91 \\
\hline \multicolumn{5}{|l|}{ Perkembangan motorik } \\
\hline Bawah rata-rata & 1 & 8,33 & 11 & 91,67 \\
\hline Rata-rata & 30 & 55,56 & 24 & 44,44 \\
\hline Atas rata-rata & 19 & 55,88 & 15 & 44,12 \\
\hline \multicolumn{5}{|l|}{ Perkembangan kognitif } \\
\hline Bawah rata-rata & 4 & 40,00 & 6 & 60,00 \\
\hline Rata-rata & 34 & 51,52 & 32 & 48,48 \\
\hline Atas rata-rata & 12 & 50,00 & 12 & 50,00 \\
\hline \multicolumn{5}{|l|}{ Perkembangan bahasa } \\
\hline Bawah rata-rata & 6 & 54,55 & 5 & 45,45 \\
\hline Rata-rata & 32 & 50,79 & 31 & 49,21 \\
\hline Atas rata-rata & 12 & 46,15 & 14 & 53,85 \\
\hline \multicolumn{5}{|c|}{ Perkembangan sosioemosional } \\
\hline Bawah rata-rata & 12 & 36,36 & 21 & 63,64 \\
\hline Rata-rata & 33 & 55,93 & 26 & 44,07 \\
\hline Atas rata-rata & 5 & 62,50 & 3 & 37,50 \\
\hline \multicolumn{5}{|l|}{ Perkembangan adaptif } \\
\hline Bawah rata-rata & 5 & 33,33 & 10 & 66,67 \\
\hline Rata-rata & 31 & 54,39 & 26 & 45,61 \\
\hline Atas rata-rata & 12 & 48,00 & 13 & 52,00 \\
\hline \multicolumn{5}{|l|}{ Pendidikan terakhir ibu } \\
\hline Tinggi & 34 & 55,74 & 27 & 44,26 \\
\hline Rendah & 16 & 41,03 & 23 & 58,97 \\
\hline \multicolumn{5}{|l|}{ Pendidikan terakhir ayah } \\
\hline Tinggi & 35 & 54,69 & 29 & 45,31 \\
\hline Rendah & 15 & 41,67 & 21 & 58,33 \\
\hline \multicolumn{5}{|l|}{ Tingkat pendapatan } \\
\hline Cukup & 43 & 51,19 & 41 & 48,81 \\
\hline Rendah & 7 & 43,75 & 9 & 56,25 \\
\hline
\end{tabular}

(20,51\%) jika dibandingkan dengan anak yang asupan energinya cukup $(6,56 \%)$. Selain itu, proporsi anak dengan asupan energi cukup sebesar $14 \%$ lebih tinggi pada anak yang perkembangan motoriknya baik. Hasil uji statistik diperoleh nilai $p=0,036$, maka dapat disimpulkan terdapat hubungan signifikan antara asupan energi dengan perkembangan motorik (Tabel 3)

Hasil analisis asupan protein menunjukkan bahwa anak dengan asupan protein kurang, lebih banyak memiliki perkembangan motorik kurang $(21,74 \%)$ jika dibandingkan dengan anak yang 
Tabel 2. Hubungan stunting dengan perkembangan motorik

\begin{tabular}{|c|c|c|c|c|c|c|}
\hline \multirow{3}{*}{ Variabel } & \multicolumn{4}{|c|}{$\begin{array}{c}\text { Hasil pengukuran } \\
\text { perkembangan motorik }\end{array}$} & \multirow{3}{*}{$\mathbf{p}$} & \multirow{3}{*}{$\begin{array}{c}\text { RP } \\
(95 \% \mathrm{Cl})\end{array}$} \\
\hline & \multicolumn{2}{|c|}{ Baik } & \multicolumn{2}{|c|}{ Kurang } & & \\
\hline & $\mathbf{n}$ & $\%$ & $\mathbf{n}$ & $\%$ & & \\
\hline \multicolumn{7}{|l|}{ Status gizi anak } \\
\hline Stunting & 39 & 78,00 & 11 & 22,00 & 0,002 & 11 \\
\hline Tidak stunting & 49 & 98,00 & 1 & 2,00 & & $(1,47-82,03)$ \\
\hline
\end{tabular}

mempunyai asupan protein cukup (9,09\%). Hasil uji statistik diperoleh nilai $p=0,101$, maka dapat disimpulkan bahwa tidak ada hubungan signifikan antara asupan protein dengan perkembangan motorik (Tabel 3).

Hasil analisis pendapatan rumah tangga menunjukkan bahwa keluarga dengan pendapatan cukup lebih banyak memiliki anak dengan perkembangan motorik kurang $(13,10 \%)$ jika

Tabel 3. Hubungan variabel luar dengan perkembangan motorik

\begin{tabular}{|c|c|c|c|c|c|}
\hline \multirow[t]{3}{*}{ Variabel } & \multicolumn{4}{|c|}{$\begin{array}{c}\text { Hasil pengukuran } \\
\text { perkembangan } \\
\text { motorik }\end{array}$} & \multirow[t]{3}{*}{$\mathbf{p}$} \\
\hline & \multicolumn{2}{|c|}{ Baik } & \multicolumn{2}{|c|}{ Kurang } & \\
\hline & $\mathbf{n}$ & $\%$ & $\mathbf{n}$ & $\%$ & \\
\hline \multicolumn{6}{|l|}{ Jenis kelamin } \\
\hline Laki-laki & 56 & 96,55 & 2 & 3,45 & $0,002^{*}$ \\
\hline Perempuan & 32 & 76,19 & 10 & 23,81 & \\
\hline \multicolumn{6}{|c|}{ Pendidikan terakhir ibu } \\
\hline Tinggi & 54 & 88,52 & 7 & 11,48 & 0,840 \\
\hline Rendah & 34 & 87,18 & 5 & 12,82 & \\
\hline \multicolumn{6}{|c|}{$\begin{array}{l}\text { Pendidikan terakhir } \\
\text { ayah }\end{array}$} \\
\hline Tinggi & 57 & 89,06 & 7 & 10,94 & 0,663 \\
\hline Rendah & 31 & 86,11 & 5 & 13,89 & \\
\hline \multicolumn{6}{|l|}{ ASI eksklusif } \\
\hline Ya & 44 & 91,67 & 4 & 8,33 & 0,278 \\
\hline Tidak & 44 & 84,62 & 8 & 15,38 & \\
\hline \multicolumn{6}{|l|}{ Riwayat BBLR } \\
\hline Tidak & 82 & 88,17 & 11 & 11,83 & 0,847 \\
\hline $\mathrm{Ya}$ & 6 & 85,71 & 1 & 14,29 & \\
\hline \multicolumn{6}{|l|}{ Asupan energi } \\
\hline Cukup & 57 & 93,44 & 4 & 6,56 & $0,036^{*}$ \\
\hline Kurang & 31 & 79,49 & 8 & 20,51 & \\
\hline \multicolumn{6}{|l|}{ Asupan protein } \\
\hline Cukup & 70 & 90,91 & 7 & 9,09 & 0,101 \\
\hline Kurang & 18 & 78,26 & 5 & 21,74 & \\
\hline \multicolumn{6}{|c|}{ Pendapatan keluarga } \\
\hline Cukup & 73 & 86,90 & 11 & 13,10 & 0,440 \\
\hline Rendah & 15 & 93,75 & 1 & 6,25 & \\
\hline
\end{tabular}

* Signifikan $(p<0,05)$ dibandingkan dengan keluarga berpendapatan rendah $(6,25 \%)$. Hasil uji statistik diperoleh nilai $p=0,440$, maka dapat disimpulkan bahwa tidak ada hubungan signifikan antara pendapatan rumah tangga dengan perkembangan motorik anak di bawah dua tahun.

Model 1 dibangun untuk menunjukkan besarnya hubungan variabel status gizi (stunting) dengan perkembangan motorik anak. Secara statistik, stunting berhubungan dengan perkembangan motorik anak $(p<0,05)$. Dilihat dari nilai $R^{2}$ sebesar 0,1484 menunjukkan bahwa model tersebut hanya bisa menjelaskan $14,84 \%$, sedangkan $85,16 \%$ dijelaskan oleh faktor lain yang tidak dimasukkan dalam model (Tabel 4).

Model 2 yang ditunjukkan pada Tabel 4 merupakan analisis untuk mengetahui hubungan variabel stunting dengan perkembangan motorik dan besarnya konstribusi dari salah satu variabel confounding yaitu jenis kelamin. Secara statistik, hasil analisis menunjukkan ada hubungan yang bermakna antara stunting dan jenis kelamin dengan perkembangan motorik $(p<0,05)$. Dilihat dari $R^{2}$ sebesar 0,2542 menunjukkan bahwa model tersebut hanya bisa menjelaskan $25,42 \%$ dan sebesar $74,58 \%$ dijelaskan oleh faktor lain yang tidak dimasukkan dalam model.

Pada model 3 yang ditunjukkan pada Tabel 4, penambahan satu variabel yaitu asupan energi digunakan untuk melihat perubahan $\mathrm{R}^{2}$. Secara statistik, hasil analisis menunjukkan hubungan yang bermakna antara stunting dan jenis kelamin dengan perkembangan motorik $(p<0,05)$, namun asupan energi tidak berhubungan dengan perkembangan motorik ( $p>0,05$ ). Jika dilihat dari $R^{2}$ sebesar 0,2825 menunjukkan bahwa model tersebut hanya bisa menjelaskan $28,25 \%$ dan sebesar $71,75 \%$ dijelaskan oleh faktor lain yang tidak dimasukkan dalam model. 
Tabel 4. Analisis multivariat

\begin{tabular}{lccc}
\hline Variabel & Model $\mathbf{1}$ & Model $\mathbf{2}$ & Model 3 \\
& OR & OR & OR \\
& $\mathbf{( 9 5 \% ~} \mathbf{~ I I )}$ & $\mathbf{( 9 5 \% ~ C l )}$ & $\mathbf{( 9 5 \% ~ C l ) ~}$ \\
& $\mathbf{p}$ & $\mathbf{p}$ & $\mathbf{p}$ \\
\hline Status gizi & 13,82 & 11,98 & 10,12 \\
Stunting & $(1,71-111,72)$ & $(1,43-100,14)$ & $(1,18-86,37)$ \\
Tidak stunting & 0,014 & 0,022 & 0,034 \\
Jenis kelamin & & 7,57 & 7,78 \\
Perempuan & - & $(1,49-38,41)$ & $(1,50-40,42)$ \\
Laki-laki & & 0,015 & 0,015 \\
Asupan energi & & & 2,76 \\
Kurang & - & - & $(0,67-11,39)$ \\
Cukup & & & 0,159 \\
\hline$R^{2}$ & 0,1484 & 0,2542 & 0,2825 \\
\hline
\end{tabular}

*Signifikan $(p<0,05)$

Berdasarkan permodelan pada Tabel 4, dapat dilihat jenis model yang lebih baik untuk dipakai sebagai bahan pertimbangan dalam melakukan intervensi. Model yang baik adalah model yang parsimoni, artinya variabel yang masuk dalam model, sebaiknya yang sedikit jumlahnya namun cukup baik untuk dapat menjelaskan faktor-faktor penting yang berhubungan dengan variabel terikat. Berdasarkan pertimbangan tersebut, maka dipilih model 2 sebagai model yang lebih baik, yang artinya stunting dan jenis kelamin merupakan faktor risiko terjadinya perkembangan motorik di bawah rata-rata atau kurang pada anak di bawah dua tahun.

Metode Bayley Scale III mengukur skala kognitif, bahasa, sosioemosional, dan kemampuan adaptif dari anak di bawah dua tahun. Untuk itu ditampilkan hasil pengukurannya sebagai berikut.

\section{Perkembangan kognitif}

Tabel 5 menunjukkan bahwa anak yang stunting lebih banyak memiliki perkembangan kognitif kurang $(12 \%)$ jika dibandingkan dengan anak yang tidak stunting (8\%). Dari hasil uji statistik diperoleh nilai $p=0,505$ yang berarti tidak terdapat hubungan signifikan antara stunting dengan perkembangan kognitif anak di bawah dua tahun.

\section{Perkembangan bahasa}

Pada Tabel 6 diketahui bahwa anak yang tidak stunting lebih banyak memiliki perkembangan bahasa kurang (12\%) jika dibandingkan dengan anak yang
Tabel 5. Hubungan stunting dengan perkembangan kognitif

\begin{tabular}{|c|c|c|c|c|c|c|}
\hline \multirow[t]{3}{*}{ Variabel } & \multicolumn{4}{|c|}{$\begin{array}{c}\text { Hasil pengukuran } \\
\text { perkembangan } \\
\text { kognitif }\end{array}$} & \multirow{3}{*}{$\mathbf{p}$} & \multirow{3}{*}{$\begin{array}{c}\text { RP } \\
(95 \% \text { Cl) }\end{array}$} \\
\hline & \multicolumn{2}{|c|}{ Baik } & \multicolumn{2}{|c|}{ Kurang } & & \\
\hline & $\mathrm{n}$ & $\%$ & $\mathbf{n}$ & $\%$ & & \\
\hline \multicolumn{7}{|l|}{$\begin{array}{l}\text { Status gizi } \\
\text { baduta }\end{array}$} \\
\hline $\begin{array}{l}\text { Tidak } \\
\text { stunting }\end{array}$ & 46 & 92,00 & 4 & 8,00 & 0,505 & 1,23 \\
\hline Stunting & 44 & 88,00 & 6 & 12,00 & & $(0,71-2,12)$ \\
\hline
\end{tabular}

Tabel 6. Hubungan stunting dengan perkembangan bahasa

\begin{tabular}{|c|c|c|c|c|c|c|}
\hline \multirow{3}{*}{ Variabel } & \multicolumn{4}{|c|}{$\begin{array}{c}\text { Hasil pengukuran } \\
\text { perkembangan } \\
\text { bahasa }\end{array}$} & \multirow{3}{*}{ p } & \multirow{3}{*}{$\begin{array}{c}\text { RP } \\
(95 \% \mathrm{Cl})\end{array}$} \\
\hline & \multicolumn{2}{|c|}{ Baik } & \multicolumn{2}{|c|}{ Kurang } & & \\
\hline & $n$ & $\%$ & $n$ & $\%$ & & \\
\hline \multicolumn{7}{|l|}{$\begin{array}{l}\text { Status gizi } \\
\text { baduta }\end{array}$} \\
\hline $\begin{array}{l}\text { Tidak } \\
\text { stunting }\end{array}$ & 44 & 88,00 & 6 & 12,00 & 0,749 & 0,83 \\
\hline Stunting & 45 & 90,00 & 5 & 10,00 & & $(0,27-2,55)$ \\
\hline
\end{tabular}

stunting (10\%). Hasil uji statistik diperoleh nilai $p=0,749$ yang berarti tidak terdapat hubungan yang signifikan antara stunting dengan perkembangan bahasa anak di bawah dua tahun.

\section{Perkembangan sosioemosional}

Tabel 7 menunjukkan bahwa anak yang stunting lebih banyak memiliki perkembangan bahasa sosioemosional yang kurang (42\%) jika dibandingkan 
dengan anak yang tidak stunting (24\%). Hasil uji statistik diperoleh nilai $p=0,056$ yang berarti tidak terdapat hubungan yang signifikan antara stunting dengan perkembangan sosioemosional anak di bawah dua tahun.

Tabel 7. Hubungan stunting dengan perkembangan sosioemosional

\begin{tabular}{|c|c|c|c|c|c|c|}
\hline \multirow{3}{*}{ Variabel } & \multicolumn{4}{|c|}{$\begin{array}{c}\text { Hasil pengukuran } \\
\text { perkembangan } \\
\text { sosioemosional }\end{array}$} & \multirow[t]{3}{*}{$p$} & \multirow{3}{*}{$\begin{array}{c}\text { RP } \\
(95 \% \mathrm{Cl})\end{array}$} \\
\hline & \multicolumn{2}{|c|}{ Baik } & \multicolumn{2}{|c|}{ Kurang } & & \\
\hline & $n$ & $\%$ & $n$ & $\%$ & & \\
\hline \multicolumn{7}{|l|}{$\begin{array}{l}\text { Status gizi } \\
\text { baduta }\end{array}$} \\
\hline $\begin{array}{l}\text { Tidak } \\
\text { stunting }\end{array}$ & 38 & 76,00 & 12 & 24,00 & 0,056 & 1,75 \\
\hline Stunting & 29 & 58,00 & 21 & 42,00 & & $(0,97-3,16)$ \\
\hline
\end{tabular}

\section{Perkembangan adaptif}

Berdasarkan Tabel 8 diketahui bahwa anak yang stunting lebih banyak memiliki perkembangan adaptif kurang $(20,41 \%)$ jika dibandingkan dengan anak yang tidak stunting $(10,42 \%)$. Hasil uji statistik diperoleh nilai $p=0,174$ yang berarti tidak terdapat hubungan signifikan antara stunting dengan perkembangan adaptif anak di bawah dua tahun.

Tabel 8. Hubungan stunting dengan perkembangan adaptif

\begin{tabular}{|c|c|c|c|c|c|c|}
\hline \multirow[t]{3}{*}{ Variabel } & \multicolumn{4}{|c|}{$\begin{array}{c}\text { Hasil pengukuran } \\
\text { perkembangan } \\
\text { adaptif }\end{array}$} & \multirow{3}{*}{$\mathbf{p}$} & \multirow{3}{*}{$\begin{array}{c}\text { RP } \\
(95 \% \mathrm{Cl})\end{array}$} \\
\hline & \multicolumn{2}{|c|}{ Baik } & \multicolumn{2}{|c|}{ Kurang } & & \\
\hline & $\mathrm{n}$ & $\%$ & $\mathbf{n}$ & $\%$ & & \\
\hline \multicolumn{7}{|l|}{$\begin{array}{l}\text { Status gizi } \\
\text { baduta }\end{array}$} \\
\hline $\begin{array}{l}\text { Tidak } \\
\text { stunting }\end{array}$ & 43 & 89,5 & 5 & 10,42 & 0,174 & 1,95 \\
\hline Stunting & 39 & 79,59 & 10 & 20,41 & & $(0,72-5,31)$ \\
\hline
\end{tabular}

\section{BAHASAN}

\section{Hubungan stunting dengan perkembangan motorik}

Stunting menggambarkan keadaan gizi kurang yang sudah berjalan lama dan memerlukan waktu bagi anak untuk berkembang serta pulih kembali. Sejumlah penelitian memperlihatkan keterkaitan antara stunting dengan perkembangan motorik dan mental yang buruk pada usia kanak-kanak dini, serta prestasi kognitif, dan prestasi sekolah yang buruk pada usia kanak-kanak lanjut (1).

Hasil penelitian pada Tabel 5 menunjukkan bahwa prevalensi stunting dari 100 baduta yang diteliti sebanyak $50 \%$. Hasil analisis pada Tabel 2 diperoleh bahwa anak yang stunting, perkembangan motoriknya lebih banyak yang kurang $(22 \%)$ jika dibandingkan dengan anak yang tidak stunting $(2 \%)$. Hasil uji statistik diperoleh nilai $p=0,002$ sehingga dapat disimpulkan ada hubungan yang signifikan antara stunting dengan perkembangan motorik anak usia di bawah dua tahun (baduta).

Hasil uji multivariat model kedua menyatakan bahwa anak yang stunting memiliki peluang 11,98 kali lebih besar untuk mempunyai perkembangan motorik di bawah rata-rata dengan adanya kontrol dari jenis kelamin. Hasil penelitian ini sejalan dengan penelitian di Banda Aceh tahun 2011 yang menunjukkan ada hubungan signifikan antara stunting dengan perkembangan motorik kasar pada anak usia 3-5 tahun (5). Selain itu, penelitian lain di Pakistan juga menunjukkan bahwa terdapat hubungan antara pertumbuhan janin dan stunting pada saat lahir dengan perkembangan motorik kasar pada bayi (6).

Hasil penelitian ini sesuai dengan pendapat bahwa anak yang stunting mengalami pertumbuhan rangka yang lambat dan pendek. Kondisi ini merupakan hasil dari periode panjang akibat tidak terpenuhinya kebutuhan makanan yang meningkatkan kesakitan, dan biasanya ditemukan di negara-negara dengan kondisi ekonomi yang buruk (7). Zat gizi memegang peranan penting dalam dua tahun pertama kehidupan. Pertumbuhan dan perkembangan sel-sel otak memerlukan zat gizi yang adekuat. Kecukupan zat gizi pada masa ini akan mempengaruhi proses tumbuh kembang anak pada periode selanjutnya.

Penelitian lain menyatakan bahwa gangguan keterlambatan perkembangan antara lain ditandai dengan lambatnya kematangan sel-sel syaraf, lambatnya gerakan motorik, kurangnya kecerdasan, dan lambatnya respon sosial. Berbagai stimulasi melalui panca indra seperti mendengar, melihat, merasa, mencium, dan meraba, yang diberikan 
selama awal kehidupan mempunyai pengaruh besar pada pertumbuhan dan maturasi otak (8).

Perkembangan kemampuan motorik bayi akan sangat membantu untuk melakukan eksplorasi dan mempraktikkan kemampuan yang baru. Hal ini dimungkinkan karena pencapaian keterampilan motorik pada tahun pertama menyebabkan meningkatnya kemandirian, memungkinkan bayi untuk menjelajahi lingkungannya dengan lebih leluasa, dan untuk memulai berinteraksi dengan orang lain. Pada tahun kedua, anak menjadi lebih terampil secara motorik dan lebih aktif, tidak lagi diam di satu tempat, tetapi ingin bergerak ke seluruh ruangan. Ahli perkembangan anak percaya bahwa aktivitas motorik selama tahun kedua berperan penting bagi perkembangan kompetensi anak. Dalam petualangan anak diperlukan sedikit batasan, kecuali untuk keamanan (9). Kualitas masa depan anak ditentukan oleh perkembangan dan pertumbuhan anak yang optimal, sehingga deteksi, stimulasi, dan intervensi berbagai penyimpangan pertumbuhan atau perkembangan harus dilakukan sejak dini. Perkembangan motorik sering diabaikan oleh dokter dan orangtua sebagai faktor yang sangat berpengaruh di masa depan. Kecerdasan motorik yang baik dapat meningkatkan kualitas hidup seseorang di masa depan (10).

\section{Hubungan jenis kelamin dengan perkembangan motorik}

Hasil analisis pada Tabel 3 menunjukkan bahwa perempuan lebih banyak mempunyai perkembangan motorik kurang $(23,81 \%)$ jika dibandingkan dengan laki-laki $(3,45 \%)$. Hasil uji statistik diperoleh nilai $p=0,002$ sehingga disimpulkan bahwa terdapat hubungan yang signifikan antara jenis kelamin dengan perkembangan motorik anak usia di bawah dua tahun (baduta).

Hasil uji multivariat model kedua menunjukkan bahwa anak perempuan memiliki risiko 7,57 kali lebih besar untuk mengalami perkembangan motorik di bawah rata-rata/ kurang jika dibandingkan dengan anak laki-laki (Tabel 4). Ada beberapa kondisi yang ikut menimbulkan adanya variasi dalam keterampilan motorik. Sebagai contoh, terdapat perbedaan jenis kelamin dalam keterampilan tertentu. Dalam perkembangan motorik, jika kepada anak laki-laki dan perempuan diberikan dorongan, perlengkapan, dan kesempatan yang sama untuk berlatih selama tahun-tahun permulaan, tidak ditemukan adanya perbedaan perkembangan antar jenis kelamin yang berarti. Meskipun demikian, karena adanya tekanan budaya, perbedaan jenis kelamin dalam perkembangan motorik mulai kelihatan sekitar usia taman kanak-kanak dan lama kelamaan perbedaan tersebut menjadi semakin jelas pada waktu anak bertambah besar (11).

\section{Hubungan riwayat ASI eksklusif dengan perkembangan motorik}

Hasil analisis riwayat pemberian ASI eksklusif menunjukkan bahwa anak yang tidak mendapatkan ASI eksklusif lebih banyak memiliki perkembangan motorik yang kurang $(15,38 \%)$ jika dibandingkan dengan anak yang mendapatkan ASI eksklusif $(8,33 \%)$. Hasil uji statistik diperoleh nilai $p=0,278$ maka dapat disimpulkan bahwa tidak ada hubungan yang signifikan antara pemberian ASI eksklusif dengan perkembangan motorik anak usia baduta (Tabel 3). Hasil penelitian ini sejalan dengan penelitian di Kota Padang yang menyatakan bahwa tidak terdapat hubungan antara pemberian ASI dengan tumbuh kembang bayi umur 6 bulan (12). Namun demikian, hal ini tidak sejalan dengan penelitian yang menyatakan bahwa terdapat hubungan yang bermakna antara pemberian ASI eksklusif dengan tumbuh kembang anak usia 0-36 bulan di Sleman Yogyakarta (13). Penelitian lain menyimpulkan bahwa pemberian ASI eksklusif pada 6 bulan pertama berhubungan dengan rendahnya risiko infeksi lambung dan tidak terdapat efek kesehatan yang merugikan pada tahun pertama kehidupan bayi. Hasil penelitian menunjukkan bahwa bayi yang diberi ASI pada umumnya memiliki nilai skor yang lebih tinggi dalam tes perkembangan, meskipun perbedaan tidak selalu signifikan. Semakin lama bayi itu disusui sendiri oleh ibunya, semakin besar manfaat yang diperolehnya pada perkembangan psikomotor (14).

Selain itu, pemberian ASI juga sangat mempengaruhi pertumbuhan dan perkembangan bayi. Bayi yang mendapatkan ASI eksklusif selama 
6 bulan memiliki pertumbuhan dan perkembangan yang lebih baik. Bayi yang diberi ASI eksklusif selama 6 bulan akan bergerak lebih aktif dan lebih cepat berjalan (15). Selain itu, pada bayi yang mendapat ASI eksklusif, pertumbuhan tinggi badannya lebih cepat dan memiliki lingkar kepala yang lebih besar pada umur 12 bulan (14).

Tidak adanya hubungan ASI eksklusif dengan perkembangan motorik baduta dapat disebabkan oleh adanya pengaruh lain seperti rendahnya pengetahuan ibu tentang pemberian ASI eksklusif, sehingga berdampak pada kualitas dan kuantitas pemberian ASI.

\section{Hubungan pendidikan orang tua dengan perkembangan motorik}

Hasil uji statistik menunjukkan nilai $p=0,840$, yang berarti bahwa tidak ada hubungan signifikan antara pendidikan ibu dengan perkembangan motorik anak baduta. Sementara ayah dan ibu dengan tingkat pendidikan yang rendah lebih banyak memiliki anak dengan perkembangan motorik kurang $(13,89 \%)$ jika dibandingkan dengan ayah yang berpendidikan tinggi $(10,94 \%)$. Hasil uji statistik diperoleh nilai $p=0,663$, maka dapat disimpulkan bahwa tidak ada hubungan yang signifikan antara pendidikan ayah dengan perkembangan motorik anak baduta (Tabel 3). Hasil penelitian ini sebanding dengan penelitian lain yang menyatakan bahwa tidak ada hubungan yang bermakna antara pendidikan ibu dengan tumbuh kembang anak usia 0-36 bulan di Sleman Yogyakarta (13).

Pendidikan orang tua merupakan salah satu faktor yang penting dalam tumbuh kembang anak. Pendidikan yang baik memungkinkan orang tua dapat menerima segala informasi dari luar terutama tentang cara pengasuhan anak yang baik, menjaga kesehatan anak, pendidikan, dan sebagainya (16). Tidak adanya hubungan pendidikan orang tua, baik ayah dan ibu dengan perkembangan motorik bisa disebabkan oleh perkembangan anak tidak saja dipengaruhi oleh pendidikan orang tua, tapi juga besarnya dukungan dari lingkungan. Tumbuh kembang anak dipengaruhi oleh frekuensi dan intensitas interaksi anak dengan lingkungannya. Interaksi yang berkualitas dan efektif akan mempunyai dampak yang baik. Sikap orang tua sangat menentukan tumbuh kembang anak. Orang tua yang mau menerima kondisi anak, memberi dukungan, serta menciptakan lingkungan yang kondusif untuk tumbuh kembang, akan mengoptimalkan tumbuh kembang anak. Sebaliknya, orang tua yang frustrasi, stres, merasa berdosa atau menolak anak, dapat menghambat tumbuh kembang anak (16).

\section{Hubungan asupan energi dengan perkembangan motorik}

Baduta dengan asupan energi kurang lebih banyak memiliki perkembangan motorik kurang $(20,51 \%)$ jika dibandingkan baduta dengan asupan energi cukup $(6,56 \%)$. Hasil uji statistik diperoleh nilai $p=0,036$, maka dapat disimpulkan bahwa ada hubungan signifikan antara asupan energi dengan perkembangan motorik (Tabel 3). Hasil uji multivariat diperoleh bahwa baduta dengan asupan energi kurang berisiko 2,76 kali mengalami perkembangan motorik kurang dibanding yang memiliki asupan gizi cukup (Tabel 4).

Hasil penelitian ini sejalan dengan penelitian yang menyatakan bahwa terdapat hubungan signifikan antara asupan energi dengan perkembangan motorik halus dan kasar (17). Komisi ahli FAO/WHO pada tahun 1971 mengemukakan bahwa konsumsi kalori harus disesuaikan dengan berat badan selama masa pertumbuhan. Kalori dalam makanan berasal dari protein, lemak, dan karbohidrat. Anak usia 1-2 tahun mempunyai kebutuhan energi sebesar 1.000 kkal. Pasokan energi terutama berasal dari karbohidrat dan lemak. Protein juga dapat digunakan sebagai sumber energi, terutama jika sumber lain sangat terbatas. Kebutuhan akan energi dapat ditaksir dengan cara mengukur luas permukaan tubuh atau menghitung secara langsung konsumsi energi yang hilang dan yang terpakai.

Hasil penelitian di Bengkulu membuktikan bahwa bayi yang mengalami keterlambatan motorik kasar sebagian besar adalah bayi dengan asupan energi $<50 \%$ AKG. Proporsi perkembangan gerak motorik kasar normal sebagian besar terdapat pada bayi dengan asupan energi 50\% AKG. 
Dalam laporan tersebut juga disebutkan bahwa sebelumnya di Pekalengan, Jawa Barat, bayi pada usia 12-18 bulan yang mendapatkan suplementasi tinggi energi dan mikronutrien mempunyai skor perkembangan motorik kasar lebih tinggi dibanding yang tidak diberikan suplementasi (18).

\section{Hubungan asupan protein dengan perkembangan motorik}

Hasil analisis asupan protein menunjukkan bahwa anak dengan asupan protein kurang, lebih banyak memiliki perkembangan motorik di bawah rata-rata/ kurang $(21,74 \%)$, jika dibandingkan dengan anak yang mempunyai asupan protein cukup $(9,09 \%)$. Hasil uji statistik diperoleh nilai $p=0,101$, maka dapat disimpulkan bahwa tidak ada hubungan signifikan antara asupan protein dengan perkembangan motorik (Tabel 3). Hasil penelitian ini tidak sejalan dengan penelitian di Kecamatan Semarang Timur yang menyatakan bahwa terdapat hubungan yang signifikan antara asupan protein dengan perkembangan motorik balita (17).

Protein adalah "makanan untuk tumbuh". Protein menyediakan elemen struktural ke setiap sel dalam tubuh. Protein bertanggung jawab dalam pertumbuhan serta perbaikan dan penggantian jaringan. Protein adalah satu-satunya zat gizi yang dapat menduplikasi sendiri jaringan tumbuh dengan cara menumpuk jutaan protein sampai masingmasing organ mencapai pertumbuhan sempurna. Dalam penelitian lain menyatakan bahwa bayi yang mengalami keterlambatan motorik kasar sebagian besar terdapat pada bayi dengan asupan protein $<50 \%$ AKG. Proporsi perkembangan gerak motorik kasar normal sebagian besar terdapat pada bayi dengan asupan protein sebesar $50 \%$ AKG (18).

Status gizi dan asupan nutrisi sangat berpengaruh terhadap kemampuan motorik anak. Pada keadaan KEP, anak menjadi tidak aktif, apatis, pasif, dan tidak mampu berkonsentrasi. Hal ini mengakibatkan anak hanya mampu melakukan kegiatan eksplorasi lingkungan fisik dalam waktu sedikit dibandingkan dengan anak yang gizinya baik, yang mampu melakukannya dalam waktu yang lebih lama. Untuk melakukan suatu aktivitas motorik, dibutuhkan ketersediaan energi yang cukup banyak.
Tengkurap, merangkak, berdiri, berjalan, dan berlari melibatkan suatu mekanisme yang mengeluarkan energi yang tinggi, sehingga penderita KEP biasanya selalu terlambat dalam perkembangan motor milestone. Sebagai contoh, pada anak usia muda, komposisi serat otot yang terlibat dalam pergerakan kontraksi kurang berkembang pada anak yang kurang gizi. Keadaan ini juga berpengaruh terhadap pertumbuhan tulang, sehingga terjadi pertumbuhan badan yang terlambat (10).

\section{Hubungan riwayat BBLR dengan perkembangan motorik}

Hasil analisis riwayat BBLR menunjukkan bahwa anak yang mempunyai riwayat BBLR, lebih banyak memiliki perkembangan motorik di bawah rata-rata atau kurang $(14,29 \%)$ dibandingkan dengan anak yang tidak memiliki riwayat BBLR $(11,83 \%)$. Hasil uji statistik diperoleh nilai $p=0,847$, maka dapat disimpulkan bahwa tidak ada hubungan yang signifikan antara riwayat BBLR dengan perkembangan motorik anak baduta (Tabel 3 ).

Hasil penelitian ini sebanding dengan penelitian yang menyatakan bahwa tidak ada hubungan yang signifikan antara berat badan lahir dengan perkembangan anak (19). Namun demikian, hal ini tidak sejalan dengan penelitian lain yang menyatakan bahwa terdapat hubungan yang signifikan antara status gizi waktu lahir dengan perkembangan anak usia prasekolah (20). Tidak adanya hubungan antara BBLR dengan perkembangan motorik dapat disebabkan oleh faktor lain, seperti: stimulasi lingkungan, status gizi, ras, dan genetik yang juga mempunyai pengaruh penting dalam perkembangan motorik (10).

\section{Hubungan pendapatan keluarga dengan perkembangan motorik}

Hasil analisis pendapatan rumah tangga menunjukkan bahwa keluarga dengan pendapatan cukup lebih banyak memiliki anak dengan perkembangan motorik di bawah rata-rata/ kurang $(13,10 \%)$ jika dibandingkan dengan keluarga berpendapatan rendah $(6,25 \%)$. Hasil uji statistik diperoleh nilai $p=0,440$, maka dapat disimpulkan bahwa tidak ada hubungan signifikan antara 
pendapatan rumah tangga dengan perkembangan motorik anak baduta (Tabel 3 ).

Hasil penelitian ini sebanding dengan penelitian yang menyatakan bahwa tidak terdapat hubungan yang signifikan antara pendapatan rumah tangga dengan perkembangan anak (17). Pendapatan keluarga yang memadai akan menunjang tumbuh kembang anak, karena orang tua dapat menyediakan semua kebutuhan anak baik yang primer maupun sekunder (16). Status gizi buruk pada anak balita akibat dari asupan gizi yang jelek, cenderung meningkat seiring dengan menurunnya kemampuan masyarakat untuk memperoleh pangan. Anak yang dibesarkan di keluarga yang berekonomi tinggi untuk pemenuhan kebutuhan gizi akan tercukupi dengan baik dibandingkan dengan anak yang dibesarkan di keluarga yang berekonomi sedang atau kurang (10). Tidak adanya hubungan antara pendapatan keluarga dengan perkembangan motorik anak dapat disebabkan oleh sebagian besar orang tua telah mampu mencukupi kebutuhan primer anak yaitu asupan energi dan protein, yang diketahui memiliki hubungan dengan perkembangan motorik anak baduta.

\section{Hubungan stunting dengan perkembangan anak}

Berdasarkan hasil pengukuran perkembangan anak dengan metode Bayley Scale of Infant Development III (Bayley-III), diperoleh data perkembangan kognitif, bahasa, sosioemosional, dan adaptif. Hasil analisis menunjukkan tidak terdapat hubungan signifikan antara stunting dengan perkembangan kognitif $(p=0,505)$ (Tabel 5), perkembangan bahasa $(p=0,749)$ (Tabel 6), perkembangan sosioemosional $(p=0,056)$ (Tabel 7 ), dan perkembangan adaptif $(p=0,174)$ (Tabel 8 ) baduta. Tidak adanya hubungan ini dapat disebabkan faktor lain seperti: stimulasi yang diberikan kepada anak, pola asuh orang tua, dan peran orang tua dalam memberikan ruang gerak bagi anak untuk beradaptasi dengan lingkungannya. Salah satu bentuknya adalah bayi harus mendapat kesempatan untuk berinteraksi dengan figure yang spesifik dan berkesinambungan secara tetap, serta mampu memenuhi kebutuhan anak dengan cepat dan tepat (21).

\section{KESIMPULAN DAN SARAN}

Sebagian besar baduta mengalami perkembangan motorik rata-rata $(54 \%)$. Terdapat hubungan yang signifikan antara stunting dengan perkembangan motorik anak baduta. Anak yang stunting memiliki peluang 11,98 kali lebih besar untuk mempunyai perkembangan motorik di bawah ratarata setelah mengendalikan variabel jenis kelamin. Tidak terdapat hubungan signifikan antara stunting dengan perkembangan kognitif, perkembangan bahasa, perkembangan sosioemosional, dan perkembangan adaptif baduta.

Keluarga sebaiknya memperhatikan asupan makan sejak masa kehamilan sampai bayi berusia 2 tahun untuk mencegah terjadinya kurang gizi dan penyakit infeksi yang berdampak pada terjadinya stunting. Untuk mengantisipasi gangguan pertumbuhan dan perkembangan pada balita, petugas puskesmas dibantu kader posyandu hendaknya lebih aktif memberikan penyuluhan dan konsultasi tentang pentingnya pemantauan pertumbuhan dan perkembangan balita. Selain itu, perlu diadakan pemantauan pertumbuhan dan perkembangan balita, sehingga dapat diketahui adanya masalah tumbuh kembang sedini mungkin. Selanjutnya, perlu adanya pengasuhan yang baik dari keluarga seperti memberikan stimulasi dan dukungan bagi anak dalam mencapai tumbuh kembang yang optimal.

\section{RUJUKAN}

1. Gibney M, Margetts B, Kearney J, Arab L. Gizi kesehatan masyarakat. Jakarta: EGC; 2008.

2. Wani Y. Perkembangan motorik kasar dan motorik halus pada anak-anak stunted usia 1-3 Tahun di pemukiman kumuh Kota Surakarta. Universitas Gadjah Mada; 2010.

3. Kementerian Kesehatan RI. Laporan riset kesehatan dasar 2013. Jakarta: Badan Penelitian dan Pengembangan Kesehatan Kementerian Kesehatan RI; 2013. 
4. Dinas Kesehatan Kabupaten Bantul. Profil gizi tahun 2012 Dinas Kesehatan Kabupaten Bantul. Bantul: Dinas Kesehatan Kabupaten Bantul; 2012.

5. Hudaini, Ahmad A, Gustiana. Hubungan stunting dan stimulasi dengan perkembangan motorik kasar pada anak taman kanak-kanak usia 3-5 tahun di Banda Aceh. J Politek Kesehat. 2011;3-6.

6. Cheung Y, Yip P, Karlberg J. Fetal growth, early postnatal growth and motor development in Pakistani infants. Int J Epidemiol. 2001;30:6674.

7. Gibson R. Antropometric assessment principles of nutritional assessment. New York: Oxford University Press; 1990.

8. Yuliana Martianto D, Briawan D, Sukandar D. Faktor-faktor yang mempengaruhi perkembangan mental, psikomotor dan perilaku bayi usia 8-11 bulan di Kota Bogor. J Media Gizi dan Kel. 2004;28(2):38-45.

9. Santrock J. Perkembangan anak edisi ke sebelas jilid 1. Jakarta: Erlangga; 2007.

10. Marmi. Asuhan neonatus, bayi, balita, dan anak prasekolah. Yogyakarta: Pustaka Pelajar; 2012.

11. Hurlock E. Perkembangan anak jilid 1 edisi ke enam. Jakarta: Erlangga; 1978.

12. Fitri $D$, Chundrayetti E, Semiarty R. Hubungan pemberian ASI dengan tumbuh kembang bayi umur 6 bulan di Puskesmas Nanggalo. J Kesehat Andalas. 2014;3(2):136-40.

13. Soepardi R. Hubungan ASI eksklusif terhadap perkembangan anak usia 0-36 bulan dan faktor yang terkait di Desa Sumberharjo Prambanan Sleman Yogyakarta. Universitas Gadjah Mada; 2009.

14. Kramer M, Guo T, Platt R, Sevkovskaya Z, Dzikovich I, Collet J, et al. Infant growth and health outcomes associated with 3 compared with 6 month of exclusive breastfeeding. Am J Clin Nutr. 2003;78:291-5.

15. Nurfika F. Hubungan antara status gizi dengan perkembangan bayi di wilayah kerja Puskesmas Banyumas. Universitas Gadjah Mada; 2010.

16. Soetjiningsih. Tumbuh kembang anak. Jakarta: EGC; 1995.

17. Susanty M, Margawati A. Hubungan derajat stunting, asupan zat gizi dan sosial ekonomi rumah tangga dengan perkembangan motorik anak usia 24-36 bulan di wilayah kerja Puskesmas Bugangan Semarang. J Nutr Coll. 2012;683-99.

18. Nurlinda A. Gizi dalam siklus daur kehidupan seri baduta (untuk anak 1-2 tahun). Yogyakarta: Penerbit Andi; 2013.

19. Pratiwi E. Hubungan berat badan lahir dengan perkembangan anak usia prasekolah. Universitas Gadjah Mada; 2011.

20. Suatiari NK, Wulandari D. Hubungan status gizi waktu lahir dengan pertumbuhan dan perkembangan anak usia prasekolah di Desa Peguyangan Kota Denpasar. J IImu Gizi. 2011;2(2):109-17.

21. Soetjiningsih. Perkembangan anak sejak pembuahan sampai dengan kanak-kanak akhir. Jakarta: Prenada Media Group; 2012. 